\title{
Biosorption of Aluminum From Aqueous Solutions by Using Macrofungus (Cortinarius armillatus): Equilibrium, Kinetic, and Thermodynamic Studies and Determination by GFAAS
}

\author{
Naeemullah $^{\mathrm{a}, \mathrm{b}}$, Mustafa Tuzen ${ }^{\mathrm{a}, *}$, Ahmet Sari $^{\mathrm{c}, \mathrm{d}}$, and Durali Mendil ${ }^{\mathrm{a}}$ \\ a Department of Chemistry, Gaziosmanpasa University, 60250, Tokat, Turkey \\ b National Centre of Excellence in Analytical Chemistry, University of Sindh, Jamshoro 76080, Pakistan \\ ${ }^{c}$ Department of Metallurgical and Material Engineering, Karadeniz Technical University, \\ 61080, Trabzon, Turkey \\ ${ }^{d}$ King Fahd University of Petroleum and Minerals, Centers of Research Excellence, \\ Renewable Energy Research Institute, Dhahran, 31261, Saudi Arabia
}

\section{INTRODUCTION}

The assessment of heavy metals in the natural environment is of great concern due to their toxicity to human life and for preserving the ecosystem as well as from an economical perspective $(1,2)$. Aluminum ( $\mathrm{Al})$ is a non-essential element which is consistently released into the environment and has widespread application in modern industries (3). Over-exposure to aluminum might be responsible for a number of health issues such as neurological and bone diseases, e.g., Alzheimer's disease, Parkinson's disease, and osteomalacia (4). For this reason, environmental pollution control authorities have imposed a tight control on the discharge of environmental wastewater containing heavy metals and other pollutants from industries to water sources (5).

Biosorption is currently considered to be an alternative process for elimination of heavy metal pollution. It is simple, low cost, efficient and an easy application for wastewater samples. In the case of aluminum, different types of adsorbents have been used (6-9), such as $\mathrm{BDH}$ activated carbons (6), algal biosorbent (7), and seaweed (8).

The present study proposes a new biosorbent for the removal of

\footnotetext{
*Corresponding autbor.

E-mail: m.tuzen@gmail.com

Tel: $+903562521616 / 3059$

Fax: +903562521585
}

\section{ABSTRACT}

By using low-cost methods and materials, the removal of toxic metals from wastewater samples is a practical approach especially for large-scale applications. Fungi are abundantly available biomaterials and can be used as efficient biosorbents. In this sense, an interesting type of macrofungus, Cortinarius armillatus (C. armillatus) was used for removal of $\mathrm{Al}$ (III) ions from aqueous solution. The sorption of $\mathrm{Al}(\mathrm{III})$ ions onto the surface of the biosorbent was investigated by FT-IR spectroscopy and the SEM technique equipped with EDX analysis. Determination of $\mathrm{Al}(\mathrm{III})$ in the aqueous solution was performed with graphite furnace atomic absorption spectrometry (GFAAS). Maximum adsorption capacity (161.23 $\mathrm{mg} \mathrm{g}^{-1}$ ) was achieved at $\mathrm{pH} 5,20^{\circ} \mathrm{C}$ and 90 minutes. The pseudo-secondorder kinetic modeling best fits the kinetic data with a regression coefficient of $>0.999$ at the employed temperatures. Thermodynamic evaluations confirmed the exothermic and spontaneous character of the biosorption process. The reusability cycling test indicated that the fungus has good sorption/desorption performance. Moreover, this macrofungus can be used as an effective biosorbent in the treatment of wastewaters containing $\mathrm{Al}(\mathrm{III})$ ion contamination, is economical, easily accessible from natural sources, and environmentally friendly. aluminum from wastewaters by using a macrofungus (C. armillatus). It is an effective and inexpensive new biosorbent biomaterial for the treatment of aqueous media, including $\mathrm{Al}(\mathrm{III})$ ions. The literature survey mentioned above indicates the absence of a systematic study, with the aim to reveal the biosorption potential of this biosorbent in the elimination of $\mathrm{Al}(\mathrm{III})$ ions from aqueous solutions.

The present work focuses on the following targets of (i) surface morphological analysis of this sorbent by using scanning electron microscopy (SEM) and energy dispersive $\mathrm{X}$-ray (EDS) analysis and investigation of the binding mechanism of Al(III) on the surface of the biosorbent by using FT-IR spectroscopy; (ii) establishment of the biosorption ability of the macrofungus to $\mathrm{Al}(\mathrm{III})$ ions from aqueous solutions by the batch system; (iii) evaluation of the effects of the batch parameters (solution $\mathrm{pH}$, sorbent concentration, contact time and temperature) on the biosorption yield of $\mathrm{Al}(\mathrm{III})$; (iv) investigation of fitness of the equilibrium data with different isotherm models in order to gain a better understanding and modeling of the biosorption processes, and (v) kinetic examination and calculation of some thermodynamic parameters in order to describe the biosorption mechanism of $\mathrm{Al}$ (III) on the C. armillatus sorbent. 


\section{EXPERIMENTAL PROCEDURE}

\section{Biomass Preparation}

The macrofungus (Cortinarius armillatus) samples were collected at Tokat city, Turkey. The collected samples were washed repeatedly with deionized water to remove extraneous materials and salts. The biomass was then dried in an oven at $100{ }^{\circ} \mathrm{C}$ for 24 hours until no variation in the sample weight was observed. The dried macrofungus biomass was chopped, sieved, and the particles (average size of 0.5 $\mathrm{mm}$ ) were used for the biosorption experiments.

\section{Reagents and Equipment}

Analytical reagent grade chemicals were used in this work. An amount of $1000 \mathrm{mg} \mathrm{L}^{-1} \mathrm{Al}(\mathrm{III})$ stock solution was prepared by dissolution of $\mathrm{AlCI}_{3}$ (Merck, Darmstadt, Germany) in distilled water. A pH meter (Sartorius pp-15, Germany) was employed to measure the $\mathrm{pH}$ values.

The Fourier Transform Infrared (FT-IR) spectra of dried biomass and Al(III)-loaded biomass were taken using a JASCO-430 model FT-IR spectrometer (JASCO Inc., Easton, USA).

Before the analysis, the completely dried sample was mixed with $\mathrm{KBr}$ which created a pellet under press. Before forming the $\mathrm{KBr}$ powder into pellets, it was pulverized to 200 mesh and then dried at approximately $110^{\circ} \mathrm{C}$ for three hours. After drying the powder, it was stored in a desiccator until spectral analysis. The spectra were recorded in the region between 4000 and $400 \mathrm{~cm}^{-1}$ wavelength with a spectral resolution of $4 \mathrm{~cm}^{-1}$ which were ratioed against a background spectrum recorded from a clean empty cell. The spectra obtained were subtracted to obtain the sample spectrum. During the analysis, the scanning speed was $2 \mathrm{~mm} / \mathrm{sec}$ and 24 scans were averaged for each spectrum.

A PerkinElmer ${ }^{\circledR}$ AAnalyst $^{\text {TM }} 700$ AAS, equipped with an $\mathrm{HGA}^{\circledR}$ graphite furnace system was used for the aluminum determination (PerkinElmer, Inc., Shelton, CT, USA). The GFAAS instrumental working parameters are listed in Table I. Pyrolytically coated graphite tubes (PerkinElmer part no. B3001264) with a platform were used. Samples of $20 \mu \mathrm{L}$ plus $5 \mu \mathrm{L}$ of $10,000 \mathrm{mg} \mathrm{L}^{-1} \mathrm{Mg}\left(\mathrm{NO}_{3}\right)_{2}$ as matrix modifier were injected into the graphite furnace using the. The signals were measured as peak areas.

\section{Batch Biosorption Procedure}

Sample solutions containing $10 \mathrm{mg} \mathrm{L}^{-1} \mathrm{Al}(\mathrm{III})$ were buffered at

TABLE I

Instrumental Settings and Analytical Conditions for GFAAS Determination of Al

\begin{tabular}{lccc}
\hline Wavelength & $309.3 \mathrm{~nm}$ & & \\
Slit width & $0.7 \mathrm{~nm}$ & & \\
Argon flow rate & $250 \mathrm{~mL} \mathrm{~min}^{-1}$ & & \\
& Temperature & Ramp Time & Hold Time \\
& $\left({ }^{\circ} \mathrm{C}\right)$ & $(\mathrm{s})$ & $(\mathrm{s})$ \\
Drying step 1 & 100 & 5 & 20 \\
Drying step 2 & 140 & 15 & 15 \\
Ashing & 1500 & 0 & 20 \\
Atomization & 2500 & 1 & 5 \\
Cleaning & 2600 & 0 & 3 \\
\hline
\end{tabular}

$\mathrm{pH} 5$ by using acetate buffer solutions. An amount of $0.1 \mathrm{~g}$ biomass was added to this solution. This mixture was shaken for the desired contact time on an electrically thermostatic reciprocating shaker (Selecta Multimatic-55, Spain) at $120 \mathrm{rpm}$. The time required for reaching the equilibrium conditions was estimated by drawing the samples at regular time intervals until equilibrium was reached. The contents of the flask were filtered through filter paper and the filtrate was analyzed for Al(III) concentration by GFAAS. The batch biosorption procedure mentioned above was repeated at different experimental parameters: contact time 5-120 minutes, pH 2-7, initial metal concentrations of 10-400 $\mathrm{mg} / \mathrm{L}$, biomass concentration of $1-20 \mathrm{~g} / \mathrm{L}$ and the temperature from 20-60 ${ }^{\circ} \mathrm{C}$. The percent biosorption of $\mathrm{Al}$ (III) was calculated as follows:

Biosorption $(\%)=\frac{\left(C_{i}-C_{f}\right)}{C_{i}} \times 100$

where $\mathrm{C}_{\mathrm{i}}(\mathrm{mg} / \mathrm{L})$ and $\mathrm{C}_{\mathrm{f}}(\mathrm{mg} / \mathrm{L})$ are the initial and final $\mathrm{Al}$ (III) concentrations, respectively.

\section{RESULTS AND DISCUSSION}

\section{SEM-EDX Results}

The surface structure of the $C$. armillatus macrofungus before and after Al(III) sorption was analyzed by SEM image EDX pattern, and the results are presented in Figures 1 (a-d). As seen from the micrographs with magnification of $1.00 \mathrm{KX}$ in Figure 1(a), the surface of $C$. armillatus has a relatively flat and compacted texture. After biosorption of $\mathrm{Al}(\mathrm{III})$, as seen from Figure 1(c), the surface of the $C$. armillatus had comparatively messier particles and paticles below $20 \mu \mathrm{m}$ settled partially on the surface. Moreover, as seen from Figure 1(e), the EDX peak pattern of the $C$. armillatus taken after the biosorption process confirmed the presence of Al(III) 


\section{Atomic $_{\text {Spectroscopy }}^{\text {to }}$ \\ 1 Vol. 38(5), Sept./Oct. 2017}
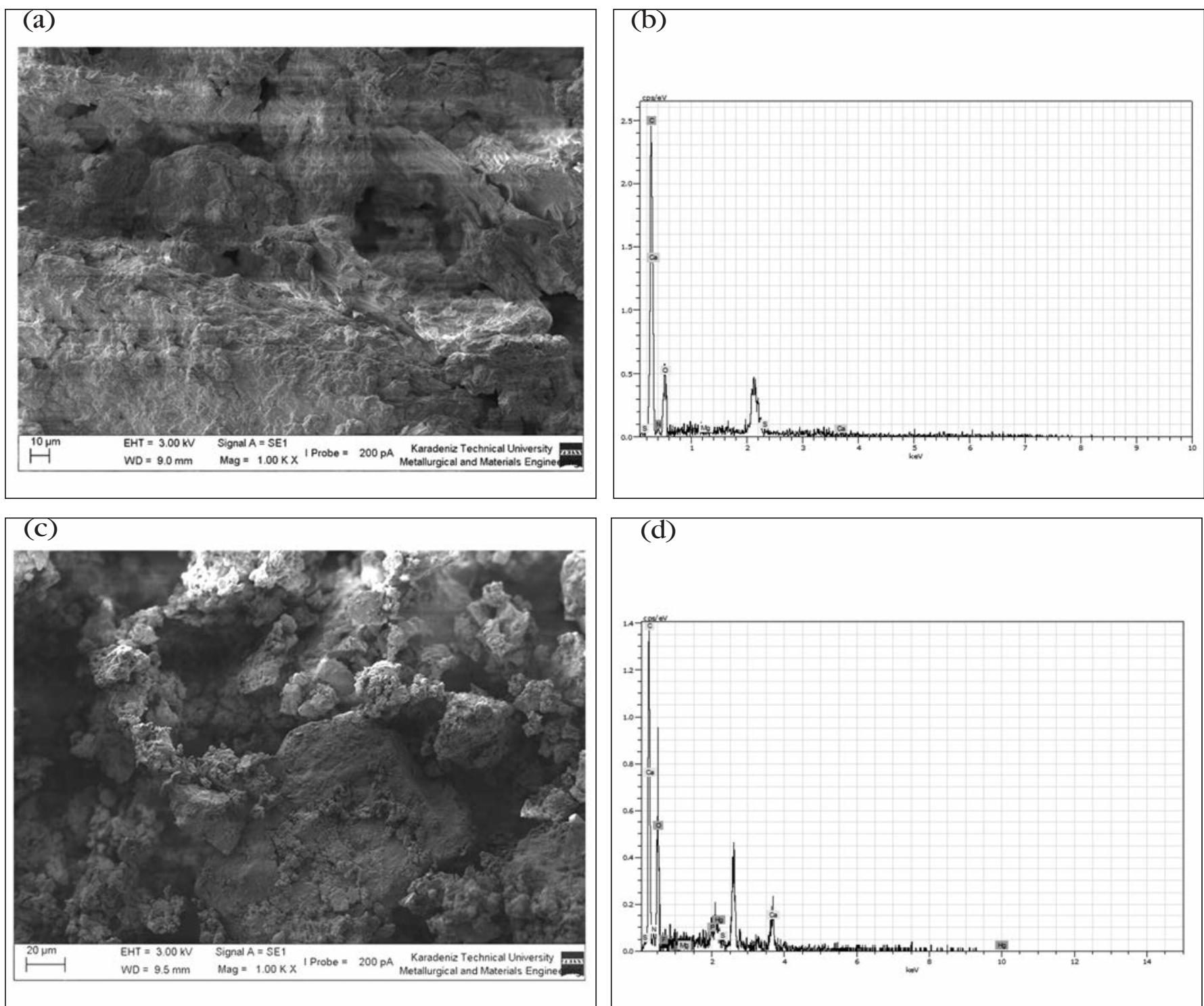

Fig. $1(a-d)$. SEM and EDX results obtained for C. armillatus biosorbent before (a, b) and after (c, d) biosorption of Al(III).

on the surface. The characteristic signal of Al(III) was not detected on the EDX pattern of the unloaded biosorbent, whereas the EDX pattern obtained after biosorption included the characteristic signal of $\mathrm{Al}$ (III).

\section{FT-IR Analysis}

The FT-IR spectroscopy technique was used to characterize the main functional groups of the C. armillatus macrofungus involved in sorbent-metal ion interactions. As seen from the spectral findings shown in Figure 2 before sorption of Al(III), the macrofungus has the following characteristic peaks: The peak recorded at $3392.17 \mathrm{~cm}^{-1}$ is attributed to the stretching vibration bands of the hydroxyl (-OH) or amine $(-\mathrm{NH})$ groups. The peaks at $2926.45 \mathrm{~cm}^{-1}$ and $1399.10 \mathrm{~cm}^{-1}$ are defined as the stretching and bending vibration bands of the $\mathrm{C}-\mathrm{H}$ groups, respectively. The band at $1644.98 \mathrm{~cm}^{-1}$ is assigned to the band and is due to the $\mathrm{C}=\mathrm{O}$ stretch- ing vibrations of the amide $I$ as the band at $1545.29 \mathrm{~cm}^{-1}$ is due to the C-N stretching vibrations in combination with the $\mathrm{N}-\mathrm{H}$ bending of the amide II band. The band observed at $1045.23 \mathrm{~cm}^{-1}$ is assigned to the -C-O stretching vibrations. Moreover, the absorption bands observed at $617.10 \mathrm{~cm}^{-1}$ are regarded to be of the phosphate groups. These results showed the existence of the functional groups (i.e., carboxyl, amino, amide, and hydroxyl) on the cell surfaces of $C$. armillatus 
macrofungus which can interact with protons or metal ions.

On the other hand, after the biosorption of $\mathrm{Al}(\mathrm{III})$, it is possible to observe some shifts in these characteristic absorption bands. The stretching vibration bands of -OH or - $\mathrm{NH}$, C-H, amide I, amide II, and the -C-O groups shifted to 3409.5, 2929.54, 1676.48, 1567.84, and $1076.08 \mathrm{~cm}^{-1}$, respectively. The change in the stretching vibration band of the -OH groups was due to its transformation from multimer to monopolymer or even the dissociative state (10) by binding of the Al(III) ions. Moreover, with $\mathrm{Al}(\mathrm{III})$ sorption, the shifts in wavelengths of the vibration bands of the - $\mathrm{NH}$, - $\mathrm{CH}$, amide I, amide II, and -C-O groups of polysaccharides, proteins, glycoproteins in the structure of the biomass were caused by ion exchange between Al(III) and the hydrogen atoms bonded to these groups. Similar properties were reported for the biosorption of some heavy metals such as $\mathrm{Pb}$ (II), $\mathrm{Cd}(\mathrm{II}), \mathrm{Cu}(\mathrm{II})$, and $\mathrm{Hg}$ (II) onto different kinds of biosorbents (11-15).

\section{Effect of Solution $\mathbf{p H}$}

The $\mathrm{pH}$ of the solution is a chief factor affecting the sorption of heavy metal ions from aqueous solutions. The change in the biosorption of $\mathrm{Al}(\mathrm{III})$ onto the $C$. armillatus based on the variation of the $\mathrm{pH}$ was evaluated and the obtained results are shown in Figure 3. As observed in this figure, at $\mathrm{pH} 2$ the biosorption efficiency was low (40\%). However, it increased quickly with an increase in $\mathrm{pH}$ and reached maximum value $(95 \%)$ at $\mathrm{pH}$ 5.0, and then decreased slowly between $\mathrm{pH} 5$ and 7 . Similar results were reported for the biosorption of $\mathrm{Cu}, \mathrm{Pb}, \mathrm{Cr}, \mathrm{Cd}$, and $\mathrm{Zn}$ by using different kinds of biomass (16-18).

The effect of $\mathrm{pH}$ can be explained based on the acidic nature and concentration of the active sites on the cell wall of the biomass. Among the functional groups of the biosorbent as active sites, especially the carboxyl groups, play an important role in the biosorption of the $\mathrm{Al}$ (III) ions. At $\mathrm{pH} 2$, the low biosorption is the result of repulsive force against the approaching $\mathrm{Al}^{3+}$ cations due to the abundantly available hydronium ions $\left(\mathrm{H}_{3} \mathrm{O}^{+}\right)$on the surface of the biosorbent. The protonated active sites $(-\mathrm{COOH})$ have low ability to bind the $\mathrm{Al}^{3+}$ ions. At a higher $\mathrm{pH}$ range ( $\mathrm{pH} 3.0-4.0$ ), a competition between $\mathrm{H}_{3} \mathrm{O}^{+}$and $\mathrm{Al}^{3+}$ is started by releasing the protons of the active sites. The more the number of anionic sites increases, the number of the $\mathrm{Al}^{3+}$ cations fixed to the surface bind Al(III) is enhanced. At $\mathrm{pH} 5.0$, by increasing the dissociation ability of the carboxyl groups, the biosorption capacity of the biomass is increased more and even reached to maximum. Moreover, the decrease observed in the biosorption percentage after $\mathrm{pH}$ 5.0 may be due to the precipitation of $\mathrm{Al}$ (III) as a result of a negatively charged surface of the biomass. Similar results were obtained for the biosorption of the Al(III) ions by different kinds of biosorbents such as Rbodococcus opacus (19), Cyanadium caldarium (20),

Padina pavonica (21), and Streptomyces rimosus (22).

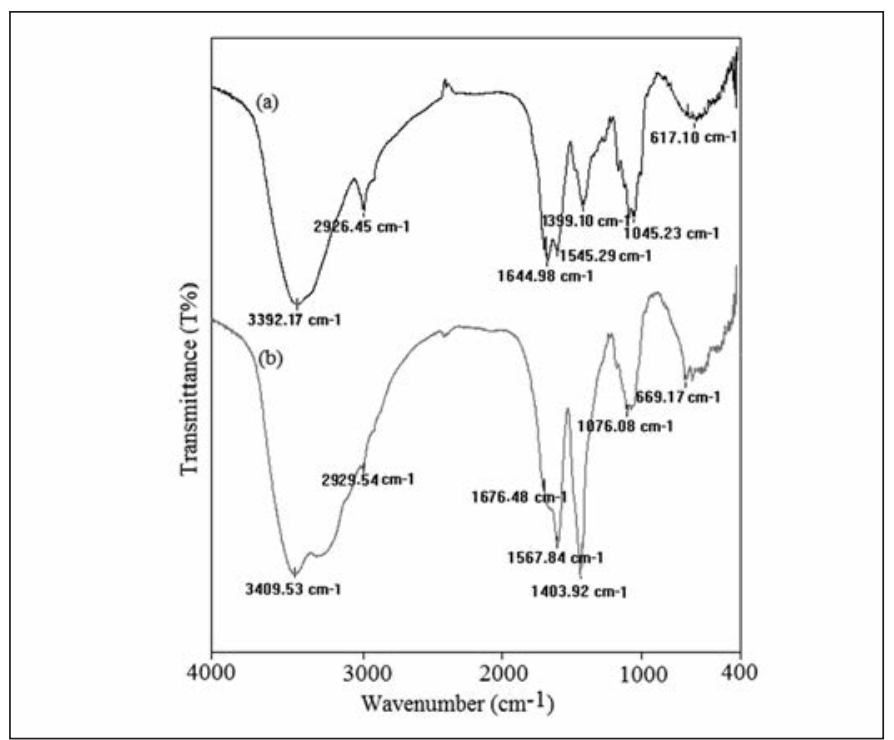

Fig. 2. FT-IR results of C. armillatus biosorbent (a) before and (b) after biosorption.

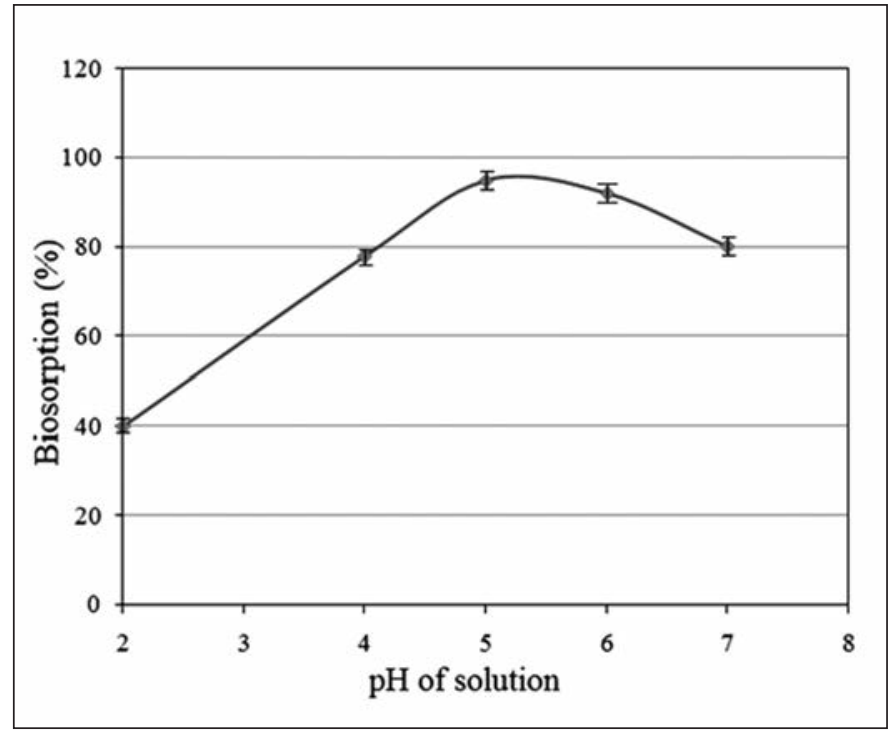

Fig. 3. Effect of $p H$ on the biosorption of Al(III) by C. armillatus biosorbent (Al(III) concentration: $10 \mathrm{mg} \mathrm{L}^{-1}$; temperature: $20^{\circ} \mathrm{C}$ ). 
Effects of Biosorbent Dosage, Contact Time and Temperature on Biosorption Efficiency

The effect of biosorbent dosage was investigated on the biosorption yield by changing the biomass concentrations from 1 to $16 \mathrm{~g} \mathrm{~L}^{-1}$ at the optimized $\mathrm{pH}$ value. As seen from Figure 4, the biosorption efficiency increased gradually from $32 \%$ to 95\% with an increase in biosorbent dosage from 1 to $8 \mathrm{~g} \mathrm{~L}^{-1}$. This is due to an increase in the number of active sites ready for sorption of the $\mathrm{Al}(\mathrm{III})$ ions with an increase in the sorbent of the solution. However, above this dosage it was almost constant due to a partial aggregation of biomass at higher biomass concentrations, resulting in a decrease in the effective surface area for the biosorption (23).

Contact time is one of many factors involved in the biosorption of heavy metals from aqueous solution (24) and influences the distribution of the metal ions between sorbent and solution. Figure 5 shows the effect of contact time on the biosorption of $\mathrm{Al}(\mathrm{III})$ at different temperatures ranging from
20 to $50^{\circ} \mathrm{C}$ and was investigated between 0 and 120 minutes. As seen from the curves, the biosorption is rapid at the contact time of 30 minutes, followed with lower rates between 30 and 90 minutes and completed at almost constant rate. This means that the biosorption of $\mathrm{Al}(\mathrm{III})$ reached equilibrium within 90 minutes. On the other hand, temperature affects the nature of the biosorption process and the sorption yield is influenced by the change of this parameter. Figure 5 also shows the dependency of the biosorption efficiency on the variation of the temperature from 20 and $50{ }^{\circ} \mathrm{C}$ under the conditions of contact time. As can be seen from the curves, the biosorption yield at $20^{\circ} \mathrm{C}$ was $95 \%$, while at $83 \%$ it was $50{ }^{\circ} \mathrm{C}$. These results confirmed the exothermic nature of the biosorption of Al(III). The decrease in the biosorption efficiency with a rise in temperature is due to the fragile interaction between biosorbent surface and the $\mathrm{Al}(\mathrm{III})$ ions and suggests physiosorption $(25,26)$.

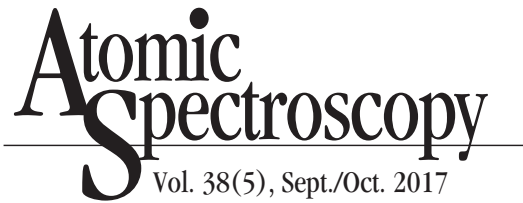

\section{Modeling the Biosorption Process}

The sorption isotherm models are applied to the sorption equilibrium data to evaluate the relationship at equilibrium between the mass of the solute sorbed per unit mass of sorbent and the metal concentration of the solution. Two isotherm models, the Langmuir and Freundlich isotherms, have been commonly used for modeling sorption processes. Three common adsorption isotherms were employed in this study. Although linear regression has been generally used as the parameters of these models; the non-linear method is sometimes preferred since this method is more convenient for consistent estimation of standard errors of the parameters (27). In this regard, the non-liner isotherm forms of the Langmuir and Freund-lich models are given below (28):

$$
q_{e}=\frac{q_{\mathrm{m}} \mathrm{K}_{\mathrm{L}} \mathrm{C}_{\mathrm{e}}}{1+\mathrm{K}_{\mathrm{L}} \mathrm{C}_{\mathrm{e}}}
$$

where $q_{\mathrm{e}}(\mathrm{mg} / \mathrm{g})$ is the equilibrium concentration of the metal ions adsorbed, $\mathrm{C}_{\mathrm{e}}(\mathrm{mg} / \mathrm{L})$ is the equilib-

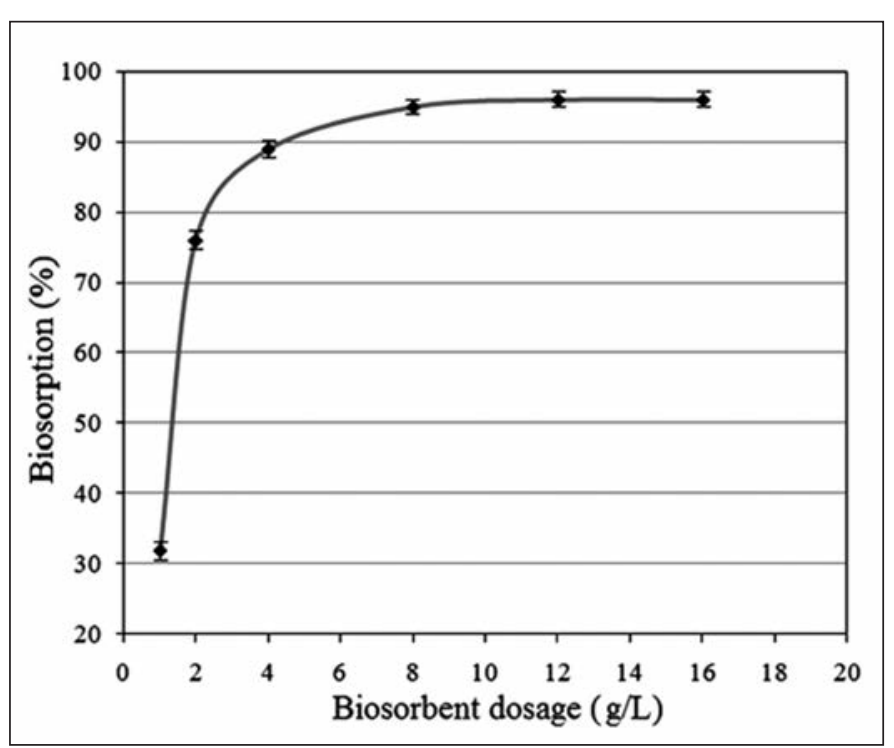

Fig. 4. Effect of biomass concentration on the biosorption of Al(III) by C. armillatus biosorbent (Al(III) concentration: $10 \mathrm{mg} \mathrm{L}^{-1}$; $\mathrm{pH}$ : 5; temperature: $20^{\circ} \mathrm{C}$ ).

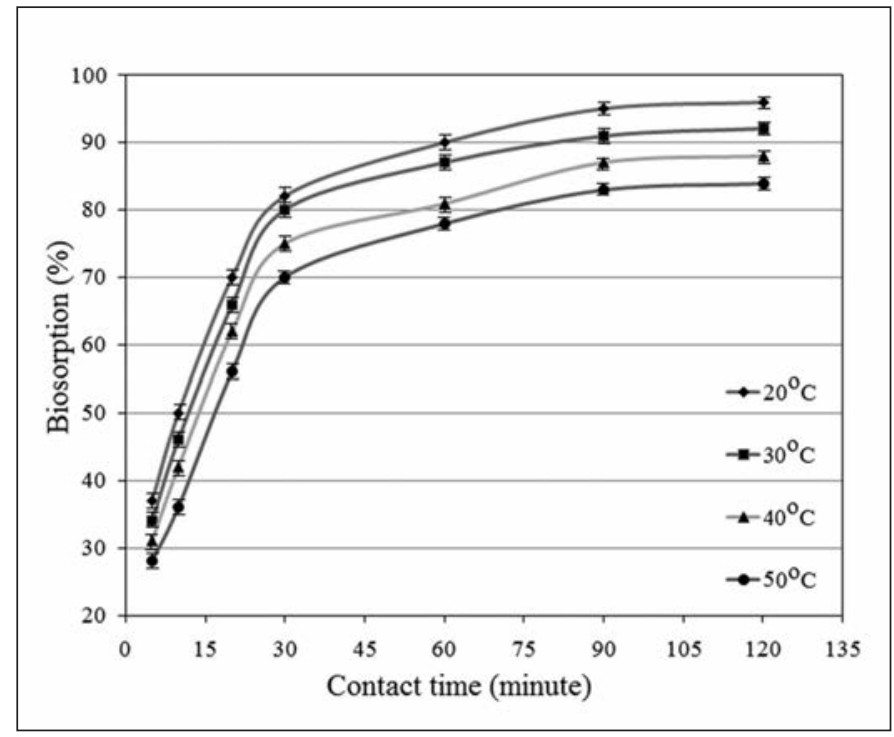

Fig. 5. Effect of contact time and temperature on the biosorption of Al(III) by C. armillatus biosorbent (Al(III) concentration: $10 \mathrm{mg} \mathrm{L}^{-1}$; biomass concentration: $8 \mathrm{~g} \mathrm{~L}^{-1}$; $\mathrm{pH}$ : 5). 
rium concentration of unsorbed metal ions and also $\mathrm{KL}(\mathrm{L} / \mathrm{mg})$ is the model constant. The Freundlich equation non-liner form is written as follow (29):

$$
q_{\mathrm{e}}=\mathrm{K}_{\mathrm{f}} \mathrm{C}_{\mathrm{e}}^{1 / n}
$$

where $K_{f}(\mathrm{mg} / \mathrm{g})$ is the model constant and $1 / n$ term is the heterogeneity factor regarded with sorption intensity. Figure 6 shows equilibrium data and their application to the non-linear Langmuir and Freundlich isotherm models for the biosorption of Al(III) onto the selected biosorbent. From the regression analysis of these nonliner plots, the correlation coefficients were determined as 0.993 and 0.971 for the Langmuir and Freundlich models, respectively. These results mean that the equilibrium data of the biosorption process fits well to the Langmuir model and the monolayer adsorption of $\mathrm{Al}(\mathrm{III})$ ions onto homogeneous sites of the biosorbent was carried out without interaction between sorbed molecules. From the non-linear Langmuir model, the maximum biosorption capacity of $\mathrm{q}_{\mathrm{m}}$ and $\mathrm{K}_{\mathrm{L}}$ constant was found as $161.23 \mathrm{mg} / \mathrm{g}$ and $1.3 \times 10^{-2} \mathrm{mg}^{-1}$, respectively. Moreover, from the Freundlich model the $\mathrm{K}_{\mathrm{f}}$ and $1 / n$ values were determined as 5.71 and 0.61 , indicating the high biosorption strength and high sorption values (30).

\section{Kinetic Examinations}

In this study, kinetic examinations were carried out in order to better understand the dynamics of biosorption of Al(III) onto $C$. armillatus and to obtain analytical results used in the evaluation of the amount of sorbed $\mathrm{Al}(\mathrm{III})$ with time and development of larger sorption systems. For this purpose, the biosorption of $\mathrm{Al}$ (III) onto C. armillatus was also examined by applying the equilibrium data to the pseudo-first (31) and second order kinetic models (32). The rearranged form of the pseudo-first-order rate equation is given below:

$$
\operatorname{In}\left(q_{\mathrm{e}}-q_{t}\right)=\operatorname{In} q_{e}-\mathrm{k}_{1} t^{\text {Eq. (4) }}
$$

where $\mathrm{q}_{\mathrm{t}}$ and $\mathrm{q}_{\mathrm{e}}$ are the amount of sorbed metal at any $t$ and equilibrium times, respectively, as $\mathrm{k}_{1}$ is the rate constant (33).

The pseudo-second-order rate is given by following equation (34).

$$
\frac{\mathrm{t}}{q_{t}}+\frac{1}{b}=\frac{1}{q_{c}}
$$

where $\mathrm{q}_{\mathrm{c}}$ and $\mathrm{q}_{\mathrm{t}}$ are the amount of sorbed $\mathrm{Hg}$ (II) at equilibrium time and any $t$ time, respectively, as $b$ is defined as initial biosorption rate. The graph representing the results obtained from the pseudo-firstorder model is not shown here because it represents the relationship with low correlation coefficients (Table II) between the $\ln \left(q_{\mathrm{e}}-q_{\mathrm{t}}\right)$ and $t$ data. On the other hand, as seen from Figure 7, the high correlation coefficients changed from 0.994-0.998 (see Table II) and the pseudo-secondorder kinetic model is more appropriate to identify the biosorption mechanism of $\mathrm{Al}(\mathrm{III})$ onto $C$. armillatus. The closeness of the calculated $\mathrm{q}_{\mathrm{e}}$ data to the experimental values is also an indicator and reveals the good fitting of the pseudo-second-order kinetic model. Furthermore, as seen from Table II, the decrease in the rate of constants with an increase in the temperature for both model equations can be evaluated as being a pointer of exothermic nature of the biosorption process.

\section{Thermodynamic Evaluation}

Thermodynamic evaluation reveals the temperature dependence and progressing character of a biosorption process, spontaneous or not. In this work, the equilibrium constant $\left(\mathrm{K}_{\mathrm{D}}\right)$ defined by Eq. (6) shows the change in free energy $(\Delta G)$, enthalpy $(\Delta H)$, and entropy $(\Delta S)$ parameters. The $K_{D}$ was calculated for 293, 303, 313 and $323 \mathrm{~K}$ and the $\Delta \mathrm{G}$ parameter was also calculated depending on the temperature by using Eq. (7). The calculated $\mathrm{K}_{\mathrm{D}}$ values were plotted vs. $1 / \mathrm{T}$ values as shown in Figure 8 , and then the $\Delta \mathrm{H}$ and $\Delta \mathrm{S}$ parameters were determined from the intercept and slope of Eq. (8), respectively (35).

$$
\begin{array}{ll}
\mathrm{K}_{\mathrm{D}}=\frac{\mathrm{C}_{\mathrm{s}}}{\mathrm{C}_{\mathrm{e}}} & \text { Eq. (6) } \\
\Delta \mathrm{G}=R \operatorname{Tln} K_{\mathrm{D}} & \text { Eq. (7) } \\
\ln K_{D}=\frac{\Delta \mathrm{S}}{\mathrm{R}}-\frac{\Delta \mathrm{H}}{\mathrm{RT}} & \text { Eq. (8) }
\end{array}
$$

From Eq. (7), the $\Delta G$ parameter was calculated for $18.93,17.99$, 17.51 , and $16.95 \mathrm{~kJ} / \mathrm{mol}$ at 293 , 303,313 , and $323 \mathrm{~K}$, respectively. The negative $\Delta G$ is an indicator of the spontaneity of the biosorption of Al(III) onto the C. armillatus process (36). From intercept and slope of the plots shown in Figure 8 , the $\Delta \mathrm{H}$ and $\Delta \mathrm{S}$ values were determined as $37.72 \mathrm{~kJ} / \mathrm{mol}$ and 64.54 $\mathrm{J} / \mathrm{mol} \mathrm{K}$, respectively. The negative $\Delta \mathrm{H}$ shows the exothermic nature of the biosorption process, while the negative $\Delta S$ means a decreased randomness at the solid solution interface during the process.

\section{Reusability of the C. armillatus Biosorbent}

The reusability of biomass is an imperative consideration in the selection of a cost-effective and practically applicable sorbent for a pilot scale bioremediation system. Therefore, an inexpensive desorbing sorbent having non-destructive sorption/desorption performance is attractive for long-term utility including multiple cycles. In this context, in order to establish the reusability of the $C$. armillatus biosorbent, the recovery process of $\mathrm{Al}$ (III) from the sorbent was carried out using $10 \mathrm{~mL}$ of $\mathrm{HNO}_{3}$ aqueous solution prepared at three different 


\section{Atomic Apectroscopy \\ $\bigcup$ Vol. 38(5), Sept./Oct. 2017}

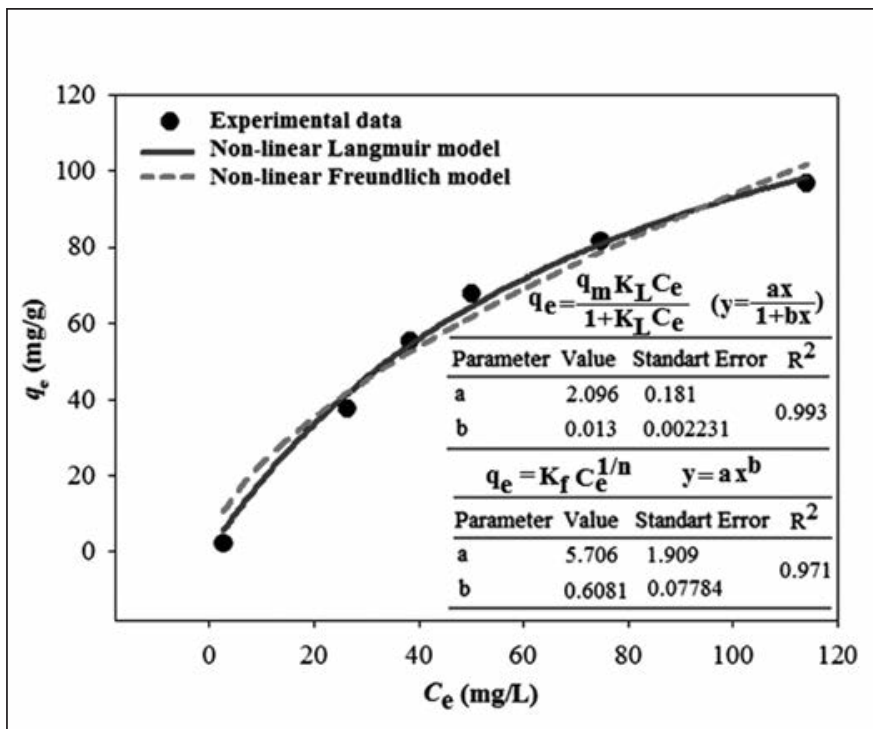

Fig. 6. Langmuir and Freundlich isotherm plots for the biosorption of Al(III) by C. armillatus biosorbent (biomass concentration: $8 \mathrm{~g} \mathrm{~L}^{-1}$; contact time: 90 minutes; $\mathrm{pH}$ : 5; temperature: $20^{\circ} \mathrm{C}$ ).

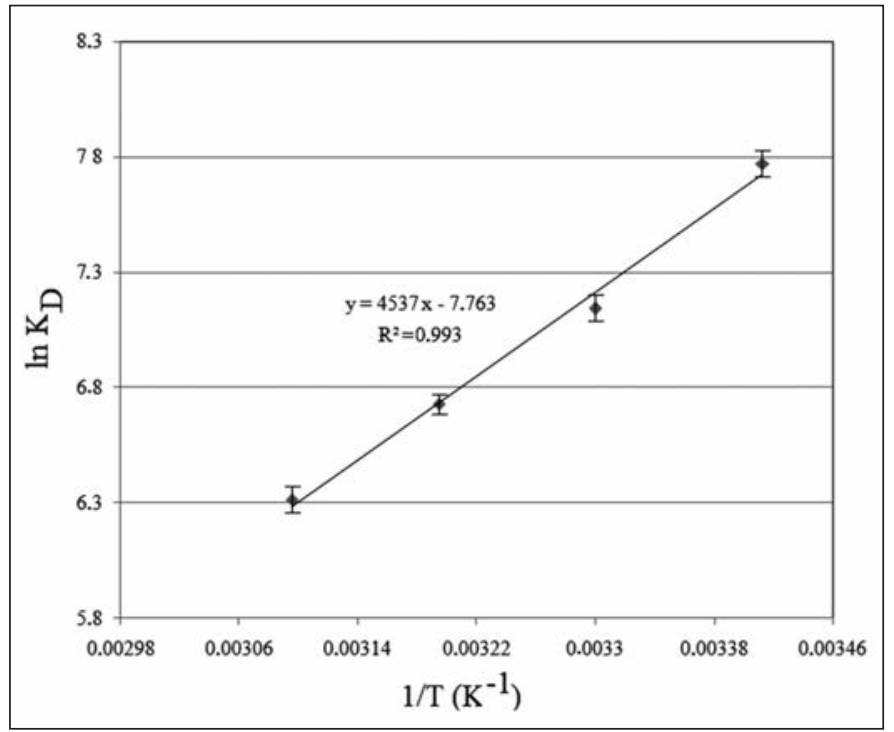

Fig. 8. Plot of $\ln K_{D}$ vs $1 / T$ for the estimation of thermodynamic parameters ( $p H$ : 5; biomass concentration: $8 \mathrm{~g} \mathrm{~L}^{-1}$; contact time: 90 minutes).

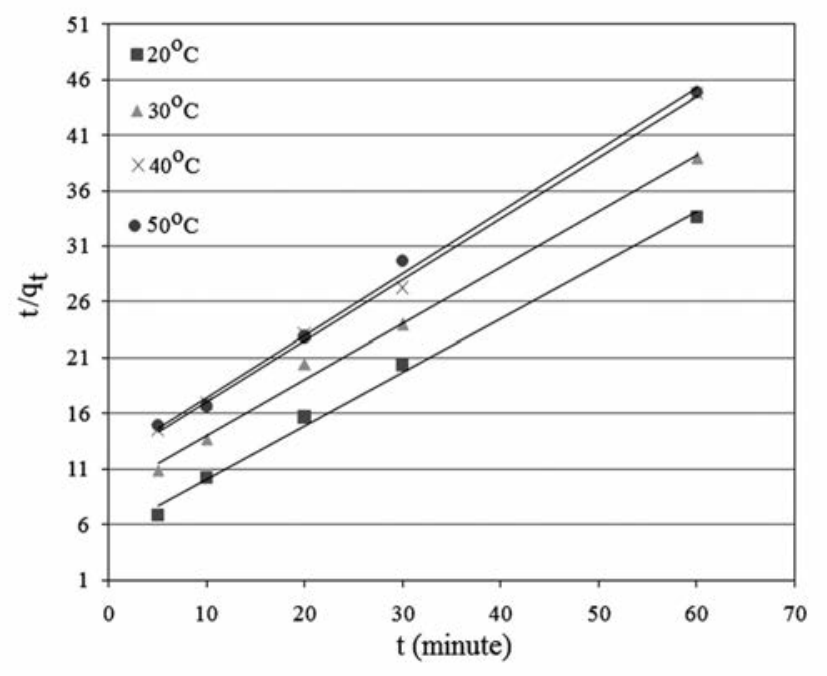

Fig. 7. The kinetic plots obtained from pseudo-second-order model at different temperatures (Al(III)) concentration: $10 \mathrm{mg} \mathrm{L}^{-1}$; $\mathrm{pH}$ : 5; biomass concentration: $8 \mathrm{~g} \mathrm{~L}^{-1}$ ).

TABLE II

Kinetic Parameters Obtained From Pseudo-firstorder and Pseudo-second-order Models at Different Temperatures (Al(III)

Concentration: $10 \mathrm{mg} / \mathrm{L}$; $\mathrm{pH}: 5$;

Biomass Concentration: $8 \mathrm{~g} / \mathrm{L}$ )

Pseudo-first- order Pseudo-second-order

Temp. $q_{e, \exp } \quad \mathrm{k}_{1} \quad q_{\mathrm{e} 1, \mathrm{cal}} R^{2} \quad \mathrm{k}_{2} \quad q \mathrm{e}_{2, \mathrm{cal}} \quad R^{2}$

$\left({ }^{\circ} \mathrm{C}\right) \quad(\mathrm{mg} / \mathrm{g})(\mathrm{L} / \mathrm{min})(\mathrm{mg} / \mathrm{g})(\mathrm{g} / \mathrm{mg}) \quad(\mathrm{L} / \mathrm{min})(\mathrm{mg} / \mathrm{g})(\mathrm{g} / \mathrm{mg})$

$\begin{array}{llllllll}20 & 2.03 & 3.3 \times 10^{-2} & 1.68 & 0.986 & 4.2 \times 10 & 2.10 & 0.995\end{array}$

$\begin{array}{llllllll}30 & 1.92 & 3.1 \times 10^{-2} & 1.60 & 0.989 & 2.8 \times 10^{-2} & 1.98 & 0.994\end{array}$

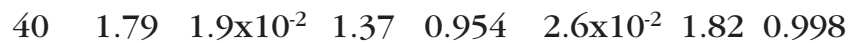

$\begin{array}{llllllll}50 & 1.76 & 1.7 \times 10^{-2} & 1.13 & 0.968 & 2.5 \times 10^{-2} & 1.79 & 0.996\end{array}$ 
concentrations of $0.1,0.25$, and $0.50 \mathrm{~mol} \mathrm{~L}^{-1}$. The desorption efficiency was found 50, 80 and $95 \%$, respectively, and thus biosorption/ desorption cycling was repeated seven times by using $10 \mathrm{~mL}$ of 0.50 $\mathrm{mol} \mathrm{L}^{-1} \mathrm{HNO}_{3}$ eluent. As seen from of the biosorption efficiency of Al(III) decreased from 96 to $65 \%$, while the desorption efficiency diminished from 95 to $61 \%$. An acceptable reduction occurred in the biosorption/desorption capacity of the macrofungus and could be attributed to the unfavorable effect of the desorptive agent on the binding sites of the fungus cell wall components which may be due to the hydrolysis of the algal cell macromolecules of the $\mathrm{HNO}_{3}$ eluent. The results indicate that the C. armillatus biosorbent showed adequately high

biosorption/desorption efficiency after seven cycling times and thus can

be used repeatedly for removal of $\mathrm{Al}(\mathrm{III})$ ions from wastewaters.

\section{Comparison of Sorption Capacity of C. armillatus With Existing Literature}

Table III presents a comparison of the sorption capacity of $C$. armilFigure 9, the desorption efficiency latus with different kinds of biomasses employed for the removal of $\mathrm{Al}$ (III) from aqueous media (11, $22,23,37-41)$. As seen from this, the maximum biosorption capacity of $C$. armillatus is higher than of the bio-sorbents listed. Moreover, the differences in the $\mathrm{q}_{\mathrm{m}}$ values can be because of the metal binding ability of the biosorbent and optimized batch conditions.

\section{CONCLUSION}

The present study focused on the investigation of the biosorption potential of $C$. armillatus macrofungus in the removal of $\mathrm{Al}(\mathrm{III})$ ions from aqueous solution. The chemical structure and morphology of this macrofungus were characterized before and after loading of Al(III) by means of the FT-IR spectroscopy method and SEM technique equipped with EDX analysis. The biosorbent has a considerably high sorption capacity (161.23 $\mathrm{mg} / \mathrm{g}$ ) at $\mathrm{pH} 5$ and the biosorption process was achieved rapidly with equilibrium conditions. Besides, the results obtained from the kinetic modeling revealed that removal of
$\mathrm{Al}(\mathrm{III})$ by $C$. armillatus is a good fit to the second-order kinetic model due to the $R^{2}$ value of $>0.99$ for all studied temperatures. Thermodynamic examinations showed that the removal of $\mathrm{Al}$ (III) by C. armillatus was carried out spontaneously and exothermally. Moreover, the sorption/desorption cycling test indicated that the fungal biomass had good reusability performance. It can be concluded that it can be used as an effective biosorbent in the treatment of wastewaters containing Al(III) ion with the added advantages of low cost, easily accessible from natural sources, and environmentally friendly. The present study has demonstrated that in combination with GFAAS, it provides a novel route for the removal of Al(III) from wastewater samples.

\section{ACKNOWLEDGMENT}

The authors are fully grateful for the financial support of the Unit of the Scientific Research Projects of Gaziosmanpasa University and to Dr. Ibrahim Turkekul for identification of the macrofungus. Dr. Mustafa Tuzen thanks the

TABLE III

Comparison of Sorption Capacity of $C$. armillatus Biosorbent With Different Biosorbents Reported in Literature

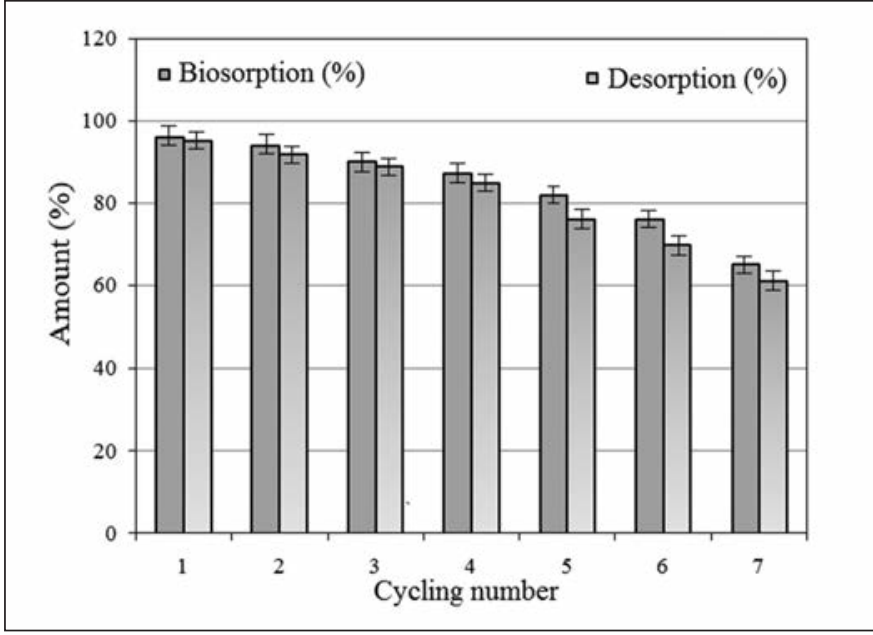

Fig. 9. Biosorption-desorption efficiency with cycle number (biomass concentration: $8 \mathrm{~g} \mathrm{~L}^{-1}$; contact time: 90 minutes; temperature: $20^{\circ} \mathrm{C}$ ).

\begin{tabular}{lcc}
\hline Biomass & $\begin{array}{c}\text { Maximum } \\
\text { Biosorption } \\
\text { Capacity } \\
\left(\mathrm{mg} \mathrm{g}^{-1}\right)\end{array}$ & Reference \\
\hline L. perlatum & 107.4 & $(15)$ \\
P. pavonica & 77.30 & $(21)$ \\
S. rimosus & 11.76 & $(22)$ \\
C. luteola TEM05 & 55.20 & $(37)$ \\
T. domingensis leaf powder & 0.35 & $(38)$ \\
R. opacus & 41.59 & $(19)$ \\
BDH activated carbon & 6.56 & $(39)$ \\
Native S. fluitan & 78.20 & $(40)$ \\
Ca-loaded S. fluitan & 75.27 & $(40)$ \\
Na-loaded S. fluitan & 104.14 & $(40)$ \\
C. baccata & 22.50 & $(41)$ \\
C. armillatus & 161.23 & In this work \\
\hline
\end{tabular}


Turkish Academy of Sciences for financial support. Naeemullah gives thanks for the Tubitak 2216 scholarship.

Received September 2, 2016.

\section{REFERENCES}

1. S. Ravikumar, A. Nural Shiefa, and E. Nishalekshami, J. Environ. Res. 12, 14 (2002).

2. S. Ravikumar, G.P. Williams, S. Shanthy, N.A.A. Gracelin, S. Babu, and P. Parimala, J. Environ. Biol, 28, 109 (2007).

3. M. Tuzen and M. Soylak, J. Hazard. Mater. 154, 519 (2008).

4. N. Jalbani, T.G. Kazi, M.K. Jamali, B.M. Arain, H.I. Afridi, and A. Baloch, J. Food Comp. Anal. 20, 226 (2007).

5. D. Kratochvil and B. Volesky, Trends Biotech. 16, 291 (1998).

6. S.A. Al-Muhtaseb, M.H. El-Naas, and S. Abdallah, J. Hazard. Mater. 158, 300 (2008).

7. H.S. Lee, J.H. Suh, I.B. Kim, and T. Yoon, Minerals engineering 17, 487 (2004).

8. H.S. Lee and J.H. Suh, Korean. J. Chem. Eng, 18, 692 (2001).

9. J. Yang, Q. Wang, Q. Luo, Q. Wang, and T. Wu, Biochem. Eng. J, 46, 294 (2009).

10. R. Kellner, J.M. Mermet, and M. Otto, Analytical Chemistry, Wiley Y-VCH Verlag GmbH Press, New York, USA, p. 824 (1998).

11. T. Akar, S. Tunali, and I. Kiran, Biochem. Eng. J. 25, 227 (2005).

12. T. Akar and $S$. Tunali, Miner. Eng. 18, 1099 (2005).

13. G. Chen, G. Zeng, L. Tang, C. Du, X. Jiang, G. Huang, H. Liu, and G. Shen, Bioresource Technol. 99, 7034 (2008).

14. R. A. Anayurt, A. Sari, and M. Tuzen, Chem. Engineering J. 151, 255 (2009).

15. A. Sar1, M. Tuzen, and D. Citak. Separation Science and Technology 47, 1167 (2012).
16. B.Y.M. Bueno, M.L. Torem, F. Molina, and L.M.S. de Mesquita, Minerals Engineering 21, 65 (2008).

17. B.A Calfa and M.L. Torem, Minerals Engineering 21, 48 (2008).

18. T.G.P. Vasquez, A.E.C. Botero, L.M.S. de Mesquita, and M.L. Torem, Minerals Engineering 20, 939 (2007).

19. J. Enrique, B. Cayllahua, and M. L. Torem, Chemical Engineering Journal 161, 1 (2010).

20. A.L.B. Marulanda, andS.W. Harcum, Waste Managmte. Environ. Restoratn. 22, 223 (2000).

21. A. Sari and M. Tuzen, J. Hazard. Mater. 171, 973 (2009)

22. A. Tassist, H. Lounici, N. Abdi, and N. Mameri, J. Hazard. Mater. 183, 35 (2010).

23. C. Gok and S. Aytas, J. Hazard. Mater. 168, 369 (2009)

24. M. Kilıc, M.E. Keskin, S. Mazluma, and N. Mazlum, Chem. Engineering and Processing 47, 31 (2008).

25. B.O. Opeolu, O. Bamgbose, and O.S. Fatoki, Water SA 37, 313 (2011).

26. M. Horsfall and A.I. Spiff, Electronic Journal of Biotechnology, 8, 162 (2005).

27. L.J.A. Gerringa, P.M.J. Herman, and T.C.W. Poortvliet, Mar. Chem. 48, 131 (1995).

28. I. Langmuir, J. Am. Chem. Soc. 40, 1361 (1918).

29. H.M.F. Freundlich, Zeitschrift für Physikalische Chemie (Leipzig, Germany), 57A, 385 (1906).

30. Y.C. Lee and S.P. Chang, Bioresour. Technol. 102, 5297 (2011).

31. S. Lagergren, Kungliga svenska vetenskapsakademiens, Handlingar 24, 1 (1898).

32. Y.S. Ho and G. Mckay, Moss Peat 34, 735 (2000).

33. R.L. Tseng, F.C. Wu, and R.S. Juang, J. Taiwan Inst. Chem. Eng. 41, 661 (2010).

34. G. Mckay, Y.S. Ho, and G. Mckay, Process Biochem. 34, 451 (1999).

\section{Atomic Spectroscopy $\bigcirc$ Vol. 38(5), Sept./Oct. 2017}

35. F. Amin, F. N. Talpur, A. Balouch, Z. A. Chandio, M. A. Surhio, and H.I. Afridi, Environmental Progress \& Sustainable Energy (in press). DOI 10.1002/ep.12342.

36. I.A. Erkaya, M.Y. Arica, A. Akbulut, and G. Bayramoglu, J. Radioanal. Nucl. Chem. 299, 1993 (2014).

37. G. Ozdemir and S.H. Baysal, Applied Microbiology and Biotechnol. 64, 225 (2004).

38. N. T. Abdel-Ghani; A. K. Hegazy; and G. A. El-Chaghaby, Int. J. Environ. Sci. Tech. 6, 243 (2009).

39. S.A. Al-Muhtaseb, M.H. El-Naas, and S. Abdallah, J. Hazard. Mater. 158, 300 (2008)

40. H.S. Lee, Biotechnol. Bioprocess. Eng. 2, 126 (1997).

41. P. Lodeiro, Á. Gudiña, L. Herrero, R. Herrero, and M. E. Sastre de Vicente, J. Hazard. Mater. 178, 861 (2010). 